www.jmscr.igmpublication.org

Impact Factor 5.244

Index Copernicus Value: 83.27

ISSN (e)-2347-176x ISSN (p) 2455-0450

crossref DOI:_http://dx.doi.org/10.18535/jmscr/v4i9.21

Journal Of Medical Science And Clinical Research

IGM Publication

An Official Publication of IGM Publication

\title{
Effect of Prosthetic Mesh in Laparoscopic Hernia Repair and Lichtenstein Procedure on Testicular Blood Flow in Patients with Inguinal Hernia
}

\author{
Authors \\ Jitendra B Bhadoria ${ }^{1}$, Nimish Shah ${ }^{2}$ \\ ${ }^{1,2}$ M.S (General Surgeon), Department of Surgery, Government Medical College Baroda, Vadodara, India \\ Corresponding Author \\ Jitendra B. Bhadoria \\ Address: 44, Durganagar So, B/h Takshashila School, Vastral, Ahmedabad-382418. \\ Email: jbroars@gmail.com, Contact no.: 9925061300
}

\begin{abstract}
Background: As there are fewer studies on the effect of mesh on testicular function, our study intends to review the safety profile of the Lichtenstein inguinal hernia repair and laparoscopic hernia repair with polypropylene mesh on male gonadal function in terms of testicular perfusion.

Aim and Objectives: To determine whether hernioplasty (open \& laparoscopic) using synthetic mesh has influence on testicular perfusion.

Methods: Data was collected from the department of surgery at SSGH in the period from January 2015 to August 2015. The patients were studied by Doppler flow parameter PSV, EDV, PI, RI pre operatively, in the early post operative period (post operative $3^{\text {rd }}$ day) and late post operative period (post operative $6^{\text {th }}$ month). Results: Total 70 patients were studied. 52 patients were operated by Lichtenstein procedure and 18 by LapTEP hernia repair with placement of prosthetic mesh. Doppler study was done postoperatively on $3^{\text {rd }}$ day and on $6^{\text {th }}$ month. Data were collected analysed for both group seperately, testicular perfusion and flow was analysed using Student Newman Kuels test to analyse within the subgroups and it showed us that there is a statistical significant difference between pre - operative and post - operative $3^{\text {rd }}$ day parameter, postoperative $3^{\text {rd }}$ day and post-operative $6^{\text {th }}$ month parameter. There is no statistical difference between preoperative parameters and post-operative $6^{\text {th }}$ month parameter. This result was seen in both group Lichtenstein as well as Lap-TEP repair.

Conclusion: No alteration in testicular volume and arterial flow after a six-month period was observed among patients who underwent surgical correction for inguinal hernia using a polypropylene prosthesis.

Keywords: Inguinal hernia, Scrotal Doppler, Lichtenstein, Lap-TEP.
\end{abstract}

\section{INTRODUCTION}

About $10 \%$ of people develop some type of hernia during their lifetime. In the USA, more than 750,000 hernia operations are performed each year. Hernias are seven times more common in males than in females. Abramson reported that the overall current risk for a male to have an inguinal hernia was $18 \%$ and the lifetime risk was $24 \%$. Hernia repair is one of the commonest surgery performed. The spermatic cord is composed of the vas deferens, testicular vessels including testicular artery and veins, autonomous nerves, spermatic muscle and fascia. Each of these structures could have various effects on testicular perfusion ${ }^{(1)}$. 
Since the original description of hernia repair by Bassini in 1889, hernia surgery underwent numerous refinement with the sole idea to reduce recurrence $^{(2)}$

Hernia repair using suture have paved the way to synthetic meshes to cover the myopectineal orifice. The most effective method of repair of inguinal hernia is by means of a tension free technique involving the use of prosthetic mesh to reinforce the abdominal wall in the region of the groin. This can be accomplished by open or laparoscopic techniques; both repairs have been shown to offer faster recovery and lower recurrence rates than the traditional method.

Every year, more than one million polypropylene prostheses are implanted for treating hernias around the world ${ }^{(3,4)}$. Over the evolution of treatments for inguinal hernia, it has been discovered that the use of prostheses is fundamental for obtaining low recurrence rates and high satisfaction rates ${ }^{(5,6,7)}$.

The euphoria triggered by the results from multicenter studies regarding the use of prosthesis made many authors conclude that the possibility of recurrence and the postoperative complications from inguinal hernias were problems that had been solved ${ }^{(8,9,10)}$.

The reproductivity of men has been a major concern throughout the history of mankind; moreover, it is accepted to be an important criteria of strength, and unfortunately, lack of reproductivity may result in an abrasive psychosocial pressure against the individuals in some communities.

The incidence of infertility among patients operated for inguinal hernias (overall) has been shown to be greater than in the general population (Shin et al., 2005). Infertility has been proposed to result from intraoperative or postoperative factors. Intraoperative factors include injury to vascular supply and to the vas deferens itself. Postoperative factor includes the fibroblastic reaction induced by the mesh, which intuitively affects the spermatic cord, which lies anterior to it. It has been shown that there is a significant decrease in the cross- sectional diameter of vas and a marked foreign body reaction to the mesh in the tissue surrounding the spermatic cord ${ }^{(11)}$.

As there are fewer studies on the effect of mesh on testicular function, our study intends to review the safety profile of the Lichtenstein inguinal hernia repair and laparoscopic hernia repair with polypropylene mesh on male gonadal function in terms of testicular volume and perfusion.

\section{PATIENTS AND METHODS}

This is a prospective observational study carried out in SSG Hospital \& Medical college Baroda during the period of January 2015 to June 2015. Cases for mesh repair by both open and laparoscopic total extraperitoneal (LT) repair were selected from the cases admitted for inguinal hernia repair at surgical units of SSG Hospital Baroda were included in the study. Adult patient of age group between $20-50$ were included. Inguinal hernia of direct and indirect types, unilateral and bilateral hernia were included. All were elective repairs. Special cases like recurrent hernia, strangulated/acute irreducible hernia were excluded. Patient selected may or may not be having respiratory, cardiac or urological pathology. Informed consent was obtained.

All patients admitted for inguinal hernias were evaluated clinically as presented in the proforma. All patients were evaluated for routine blood examination like $\mathrm{Hb}$, TC, DC, RBS, Blood Urea, Serum Creatinine, Urine examination done. Baseline ECG \& Chest X-Ray was done in all patient. Shaving (nipple to knee) was done prior to surgery and povidone iodine scrub applied in the morning of the surgery. A single dose of intravenous Cefotaxime $1 \mathrm{gm}$ was administered just before the incision kept.

All the patients were investigated for pre and post operative scrotal Doppler ultrasonography and semen analysis. All colour Doppler ultrasonographies were performed with patient in the supine position with the transducer placed gently on the scrotum by consultant radiologist. After evaluation of the testicular parenchyma and 


\section{JMSCR Vol||04||Issue||09||Page 12434-12440||September}

intra testicular blood flow, testicular artery was examined for: Peak systolic velocity (PSV), End diastolic velocity (EDV), Resistivity index (RI), Pulsatility index(PI).

Doppler flow parameter PSV, EDV, PI, RI was measured pre operatively, in the early post operative period (post operative $3^{\text {rd }}$ day) and late post operative period ( post operative $6^{\text {th }}$ month). Testicular volume was also measured.

\section{STATISTICAL METHODS}

The comparision between the pre-operative and post-operative doppler parameter for testicular perfusion were analysed by applying analysis of variance (ANOVA) method. Student Newman
Keuls test was used to analysed between the subgroups, to find the statistical difference between them.

\section{RESULTS}

This prospective observational study entitled "Effect of prosthetic mesh in laparoscopic hernia repair and lichtenstein procedure on testicular blood flow and testicular volume in patients with inguinal hernia" was conducted in SSG Hospital Baroda. It included 77 male patients between 20 to 50 years age group. Seven patients were lost to follow up till 6 month, hence excluded from the study.

Table 1: Age distribution

\begin{tabular}{|l|c|c|c|}
\hline AGE GROUP & LICHTENSTEIN & LAP-TEP & TOTAL \\
\hline $20-30$ & 17 & 00 & 17 \\
\hline $31-40$ & 27 & 06 & 33 \\
\hline $41-50$ & 08 & 12 & 20 \\
\hline
\end{tabular}

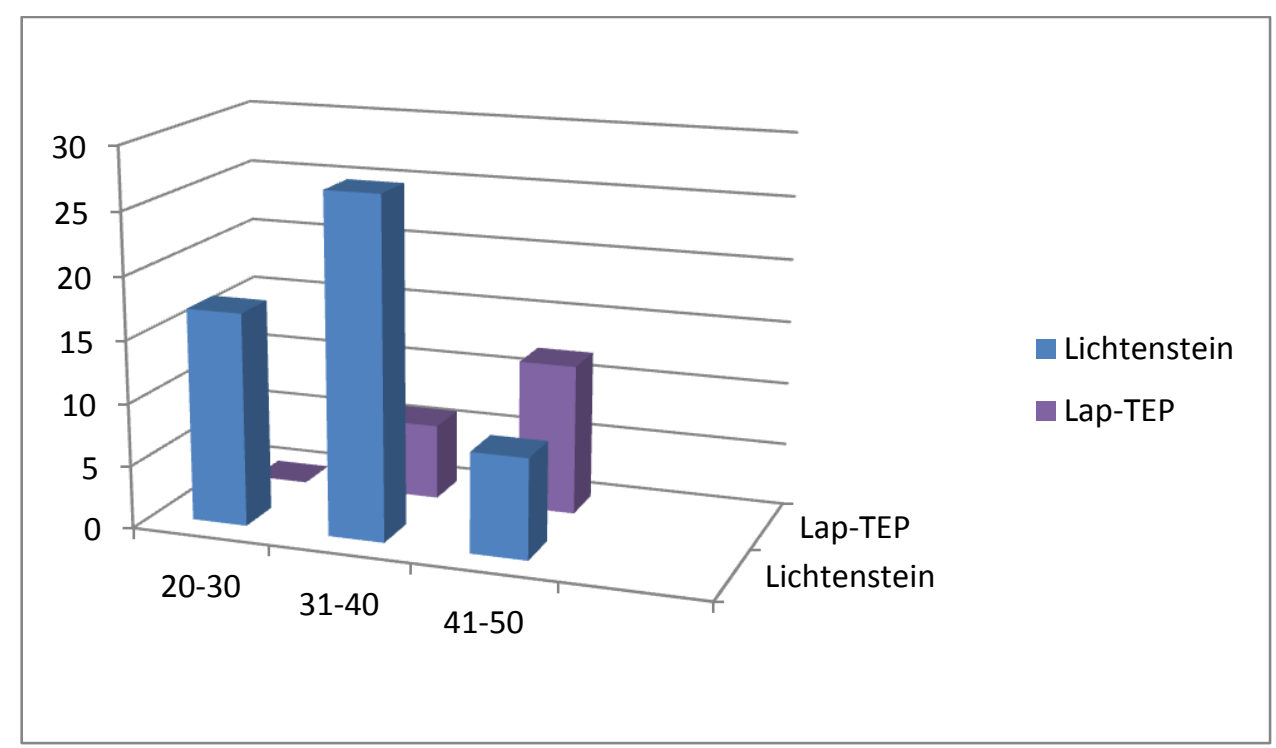

Table shows that 52 patients were operated by Lichtenstein procedure and 18 by Lap- TEP procedure. Most common age group was age 31-40 years.

Table $2 \mathrm{~A}$ : Results of doppler parameter with their range in Lichtenstein group

\begin{tabular}{|l|c|c|c|c|}
\hline $\begin{array}{l}\text { SR } \\
\text { NO. }\end{array}$ & $\begin{array}{c}\text { DOPPLER } \\
\text { PARAMETERS }\end{array}$ & $\begin{array}{c}\text { PRE- } \\
\text { OPERATIVE }\end{array}$ & $\begin{array}{c}\text { POST-OPERATIVE } \\
\mathbf{3}^{\text {RD }} \text { DAY }\end{array}$ & $\begin{array}{c}\text { POST-OPERATIVE 6 } \\
\text { MONTH }\end{array}$ \\
\hline 1 & PSV $(\mathrm{cm} / \mathrm{s})$ & $9.8-11.90$ & $16.5-18.6$ & $10.2-11.6$ \\
\hline 2 & EDV $(\mathrm{cm} / \mathrm{s})$ & $2.03-2.20$ & $1.80-2.03$ & $2.05-2.17$ \\
\hline 3 & PI & $0.53-0.68$ & $0.63-0.78$ & $0.52-0.67$ \\
\hline 4 & RI & $0.42-0.54$ & $0.54-0.71$ & $0.42-0.52$ \\
\hline
\end{tabular}


Table 2 B: Comparision between Pre-operative and Post-operative doppler parameters for Lichtenstein procedure

\begin{tabular}{|l|c|c|c|c|c|}
\hline $\begin{array}{l}\text { SR } \\
\text { NO. }\end{array}$ & $\begin{array}{c}\text { DOPPLER } \\
\text { PARAMETERS }\end{array}$ & $\begin{array}{c}\text { PRE- } \\
\text { OPERTIVE } \\
(\text { MEAN) }\end{array}$ & $\begin{array}{c}\text { POST- } \\
\text { OPERATIVE } \\
\mathbf{3}^{\text {RD }} \text { DAY } \\
(\text { MEAN) }\end{array}$ & $\begin{array}{c}\text { POST- } \\
\text { OPERATIVE } \\
\text { 6 }^{\text {TH }} \text { MONTH } \\
(\text { MEAN) }\end{array}$ & $\begin{array}{c}\text { LICHTENSTEIN } \\
\text { (P VALUE) }\end{array}$ \\
\hline 1. & PSV (cm/s) & 11.008 & 17.48 & 10.85 & $\mathrm{P}<0.001$ \\
\hline 2. & EDV (cm/s) & 2.08 & 1.91 & 2.12 & $\mathrm{P}<0.001$ \\
\hline 3. & PI & 0.59 & 0.70 & 0.59 & $\mathrm{P}<0.001$ \\
\hline 4. & RI & 0.47 & 0.61 & 0.46 & $\mathrm{P}<0.001$ \\
\hline
\end{tabular}

The difference within the patients operated by Lichtenstein procedure, before surgery and after surgery at two distinct points $\left(3^{\text {rd }}\right.$ day and $6^{\text {th }}$ month) with regards to PSV values was measured by using analysis of variance (ANOVA). ANOVA showed significant difference within this group.

ANOVA also showed significant difference for the other doppler parameters such as EDV, PI and RI.

Table 3 : Student Newman Keuls test for all pair wise comparisons for Lichtenstein procedure

\begin{tabular}{|c|c|c|c|c|}
\hline & PSV & EDV & PI & RI \\
\hline Pre-operative & 2 & 2 & 2 & 2 \\
\hline Post-op $3^{\text {rd }}$ day & 1,3 & 1,3 & 1,3 & 1,3 \\
\hline Post-op $6^{\text {th }}$ month (3) & 2 & 2 & 2 & 2 \\
\hline
\end{tabular}

Now, to check a pairwise difference Student Newman Keuls test was used and it showed statistical difference between pre-operative and post-operative third day. It also showed the statistical difference between post-operative third day and post - operative six month for all four doppler parameters (PSV, EDV, PI, RI).

Student Newman Keuls test does not showed the statistical significant difference between preoperative and post-operative six month for PSV, EDV, PI and RI.

Table 4 A: Results of doppler parameter with their range in Lap - TEP group :

\begin{tabular}{|l|l|c|c|c|}
\hline $\begin{array}{l}\text { SR } \\
\text { NO. }\end{array}$ & $\begin{array}{l}\text { DOPPLER } \\
\text { PARAMETERS }\end{array}$ & $\begin{array}{c}\text { PRE- } \\
\text { OPERATIVE }\end{array}$ & $\begin{array}{c}\text { POST-OPERATIVE } \\
\mathbf{3}^{\text {RD }} \text { DAY }\end{array}$ & $\begin{array}{c}\text { POST-OPERATIVE 6 } \\
\text { MONTH }\end{array}$ \\
\hline 1 & PSV $(\mathrm{cm} / \mathrm{s})$ & $10.2-11.90$ & $15.4-18.0$ & $10.3-11.8$ \\
\hline 2 & EDV $(\mathrm{cm} / \mathrm{s})$ & $2.02-2.20$ & $1.83-2.01$ & $2.01-2.17$ \\
\hline 3 & PI & $0.52-0.65$ & $0.66-0.74$ & $0.52-0.66$ \\
\hline 4 & RI & $0.43-0.54$ & $0.55-0.71$ & $0.43-0.52$ \\
\hline
\end{tabular}

Table 4 B: Comparision between Pre-operative and Post-operative doppler parameters for Lap-TEP procedure

\begin{tabular}{|l|c|c|c|c|c|}
\hline $\begin{array}{l}\text { SR } \\
\text { NO. }\end{array}$ & $\begin{array}{c}\text { DOPPLER } \\
\text { PARAMETERS }\end{array}$ & $\begin{array}{c}\text { PRE- } \\
\text { OPERTIVE } \\
\text { (MEAN) }\end{array}$ & $\begin{array}{c}\text { POST- } \\
\text { OPERATIVE 3 } \\
\text { DAY (MEAN) }\end{array}$ & $\begin{array}{c}\text { POST-OPERATIVE } \\
\text { 6 }^{\text {TH }} \text { MONTH } \\
\text { (MEAN) }\end{array}$ & $\begin{array}{c}\text { LAP-TEP } \\
\text { (P VALUE) }\end{array}$ \\
\hline 1. & PSV (cm/s) & 10.97 & 17.19 & 11.03 & P $<0.001$ \\
\hline 2. & EDV (cm/s) & 2.14 & 1.91 & 2.12 & P $<0.001$ \\
\hline 3. & PI & 0.59 & 0.68 & 0.59 & $\mathrm{P}<0.001$ \\
\hline 4. & RI & 0.48 & 0.61 & 0.47 & $\mathrm{P}<0.001$ \\
\hline
\end{tabular}




\section{JMSCR Vol||04||Issue||09||Page 12434-12440||September}

The difference within the patients operated by Lap-TEP procedure, before surgery and after surgery at two distinct points $\left(3^{\text {rd }}\right.$ day and $6^{\text {th }}$ month) with regards to PSV values was measured by using analysis of variance (ANOVA). ANOVA showed significant difference within this group.

ANOVA also showed significant difference for the other doppler parameters such as EDV, PI and RI.

Table 5 : Student Newman Keuls test for all pairwise comparisons for Lap-TEP procedure

\begin{tabular}{|c|c|c|c|c|}
\hline & PSV & EDV & PI & $\mathbf{R I}$ \\
\hline Pre-operative & 2 & 2 & 2 & 2 \\
\hline Post-op $3^{\text {rd }}$ day & 1,3 & 1,3 & 1,3 & 1,3 \\
\hline Post-op $6^{\text {th }}$ month (3) & 2 & 2 & 2 & 2 \\
\hline
\end{tabular}

Now, to check a pair wise difference Student Newman Keuls test was used and it showed statistical difference between pre-operative and post-operative third day. It also showed the statistical difference between post-operative third day and post - operative six month for all four doppler parameters (PSV, EDV, PI, RI).

Student Newman Keuls test does not showed the statistical significant difference between pre- operative and post-operative six month for PSV, EDV, PI and RI.

\section{DISCUSSION}

This is a prospective observational study carried out in SSG Hospital \& Medical College Baroda during the period of January 2015 to June 2015, the effect of prosthetic mesh in inguinal hernia surgery on and testicular perfusion was evaluated.

\section{Comparisions of results with other studies:}

Analysis of the testicular flow

\begin{tabular}{|l|c|c|c|c|c|c|}
\hline Study & & A & B0 & B1 & C & P value \\
\hline \multirow{4}{*}{ H. AYEDE ET AL. } & PSV & 11.13 & 10.5 & - & 10.8 & $<0.001$ \\
\cline { 2 - 7 } & EDV & 3.1 & 2.9 & - & 1.4 & $<0.001$ \\
\cline { 2 - 7 } & PI & 1.3 & 1.6 & - & 0.7 & $>0.05$ \\
\cline { 2 - 7 } & RI & 0.6 & 0.71 & - & 2.82 & $<0.001$ \\
\hline \multirow{3}{*}{ S. HATIPOGLU ET AL. } & RI & 0.46 & - & 0.42 & 0.53 & $>0.05$ \\
\hline \multirow{4}{*}{ EDGAR ET AL. } & PSV & - & - & - & - & 0.25 \\
\cline { 2 - 7 } & EDV & - & - & - & - & 0.554 \\
\cline { 2 - 7 } & PI & - & - & - & - & 0.99 \\
\cline { 2 - 7 } & RI & - & - & - & - & 0.58 \\
\hline KUMAR ET AL. & RI & 0.53 & 0.63 & 0.53 & 0.54 & 0.9 \\
\hline \multirow{5}{*}{ OUR STUDY } & PSV & 11.08 & 17.78 & - & 10.85 & $<0.001$ \\
\cline { 2 - 7 } & EDV & 2.08 & 1.91 & - & 2.12 & $<0.001$ \\
\cline { 2 - 7 } & PI & 0.59 & 0.70 & - & 0.59 & $<0.001$ \\
\cline { 2 - 7 } & RI & 0.47 & 0.61 & - & 0.46 & $<0.001$ \\
\hline
\end{tabular}

A: Pre-operative, B0 : Early post-opertive $3^{\text {rd }}$ day- $2^{\text {nd }}$ week, B1 : Intermediate post-operative period $4^{\text {th }}$ week -2 month, C : Late postoperative $6^{\text {th }}$ month.

H. Aydede et al reported statistical significant difference between pre-operative PSV versus early postoperative PSV, pre-operative EDV versus early postoperative EDV, pre-operative RI versus early postoperative RI although there was no significant difference in pre-operative PI versus early postoperative PI. However no statistically significant difference was found between preoperative and late postoperative values in terms of Doppler flow parameters. Sinan Hatipoglu et al reported no significant differences between the 
pre-operative and post-operative RI values of testicular and capsular arteries in both groups. Edgar Valente et al, reported no statistically significant alterations in the variables studied were observed pre-operatively and $3^{\text {rd }}$ month, $6^{\text {th }}$ month post-operatively: systolic velocity; diastolic velocity; resistance index; and pulsatility index. Kumar et al, reported 78 (90.69\%) patients had increased TARI on Right side at 2nd post-op week $(P=0.000)$. There was no significant effect of Lichtenstein repair on TARI found at 8 th week, and 6th month of follow up postoperatively. On the Left side around $63(73.25 \%)$ patients had increased TARI at 2ndpost-op week $(P=0.000)$. There was no significant effect of Lichtenstein repair on TARI at 8th week, and 6th month of postoperative follow up.

In our study we observed testicular flow on three occasions and there was statistical signifance difference between doppler parameters such as PSV,EDV,PI and RI between pre-operative and early post-operative, between early post-operative and late post- operative doppler flow parameter. We found no statistical signifance difference between pre-operative and late post-operative doppler parameter. This decreased early postoperative testicular flow in both groups can be explained by traumatic tissue oedema rather than inflammatory tissue reaction.

\section{CONCLUSION}

Present study concluded that, there is a mild reduction in testicular flow in the early postoperative period, suggested by the slight increase in resistance index and decrease in end diastolic volume in early post-operative period, which may due to the operative trauma and edema in the tissue in early post-operative period.

But over a period of six month this testicular flow parameter returns to normal. This indicates chronic tissue inflammation against mesh have no adverse effect on testicular perfusion over time.

\section{ACKNOWLEDGEMENT}

This study has only been possible as a result of the help; we have received from so many people. We are thanking to our ex-head of department Dr. V.P.Hathila, my guide Dr. Nimish Shah, Dr. Digant Patel, my colleagues Dr. Dipak, Dr. Jignesh, Dr. Burhan, Dr Ashwin and juniors. We are also thank full to all patients who had given consent to be a part of this. In addition, there are many un-named colleagues whom we wish to thank. We would like to thank our immediate families for all their support and in particular our long-suffering spouse. All the time spent on preparation is time when we have been unavailable for them.

\section{REFERENCES}

1. Dilek: Hernioplasty and testicular perfusion Springer Plus 2014 3:107.

2. Bailey M. The case for laparoscopic repair. Ann R Collsurg Eng 12005;87-57-58

3. Coob WS, Kercher KW, Heniford T. The argument for lightweight polypropilene mesh in hernia repair. Surg Inn. 2005;12(1):20-7.

4. Klosterhalfen B, Junge K, Klinge U. The lightweight and large porus mesh concept for hernia repair. Exp Rev Med Dev. 2005;2(1):1-15.

5. Shulman AG, Amid PK, Lichtenstein IL. A survey of non-expert surgeons using the open tension-free mesh patch repair for primary inguinal hernias. Int Surg. 1995;80:35-6.

6. Zieren J, Beyersdorff D, Beier KM, Müller JM. Sexual function and testicular perfusion after inguinal hernia repair with mesh. Am J Surg. 2001;181:204-6.

7. Amid PK. Lichtenstein tension-free hernioplasty: its inception, evolution and principles. Hernia. 2004;8(1):1-7.

8. Wantz GE. Testicular atrophy as a risk of inguinal hernioplasty. Surg Gynecol Obstet. 1982;154:570-1. 
9. Amid PK, Lichtenstein IL. Long-term result and current status of the Lichtenstein open tension-free hernioplasty. Hernia. 1998;89(2):89-94.

10. Amid PK, Friis E, Horeyseck, Kux M. A multi-center experience with 6,764 Lichtenstein tension-free herniplasties. Hernia. 1999; 3:47-8

11. Shin D1, Lipshultz LI, Goldstein M, Barmé GA, Fuchs EF, Nagler HM, McCallum SW, Niederberger CS, Schoor RA, Brugh VM 3rd \& Honig SC (2005). Herniorrhaphy with polypropylene mesh causing vassal obstruction: a preventable cause of obstructive azoospermia. Annals of Surgery, 241(4) 553-558

12. Bakırköy Tıp Dergisi, Cilt 6, Sayı 1, 2010 / Medical Journal of Bakırköy, Volume 6, Number 1, 2010

13. Ind. J. Sci. Res. and Tech. 2015 3(4):6671/Kumar et al ISSN:-2321-9262

14. Lima Neto EV, Goldenberg A, Jucá MJ. Prospective study on the effects of a polypropylene prosthesis on testicular volume and arterial flow in patients undergoing surgical correction for inguinal hernia. Acta Cir Bras. [serial on the Internet] 2007 July-Aug 22(4).

15. H. Aydede*, Y. Erhan*, A. Sakarya*, E. Kara**, Ö. I.lkgül**, M. Can***Effect of Mesh and its Localisation on Testicular Flow and Spermatogenesis in Patients with Groin Hernia Acta chir belg, 2003, 103, 607-610

16. Amid PK, Shulman AG, Lichtenstein IL. Acritical comparision of laparoscopic hernia repair with Lichtenstein tension free hernioplasty. Med J Australia 1994;161: 239-40

17. Polglase AL, McMurrick. The cut or the key hole? Laparoscopic or open hernia repair of inguinal hernia? Med J Australia 1994;161:238-239
18. Arregui ME, Navarrete J, Davis CJ et al. Laparoscopic inguinal herniorrhaphy. Results of a multicenter Trial. Ann Surg 1995;73(3):513-527

19. Kavis MS. Laparoscopic hernia repair. Surg Endosc 1993;7:163-167

20. Cornell PB, Kerlakian GM. Early complications and outcomes of the current technique of transperitoneal open approach. Am J Surg 1994;168: 275-279

21. Horton MD, Florence MG. Simplified properitoneal marlex hernia repair. Am J Surg 1993;165:595-59

22. Zieren J, Zieren HU, Wenger FA et al. Laparoscopic or conventional repair of inguinal hernia with synthetic mesh? Langenbacks Arch Chir 1996;381:289-294

23. Amid PK, Shulman AG, Lichtenstein IL, Hakhakha M. The goals of modern surgery. How to achieve them. Prob Gen Surg, 12:165-171

\section{LIST OF ABBREVEATIONS}

LICH Lichtenstein

Lap-TEP Laparoscopic total extraperitoneal PSV Peak sytolic velocity

EDV End diastolic velocity

PI Pulsatility index

RI Resistance index

TV Testicular volume

SC Sperm count

SM Sperm motility

ANOVA Analysis of variance

Pre-op Pre-operative

Post-op Post-operative 